\title{
First Molecular Characterization of Posthodiplostomum cuticola (von Nordmann, 1832) Dubois, 1936 (Trematoda: Diplostomidae) Metacercariae Infecting the Gills of Chubs (Squalius cephalus) in Turkey
}

\author{
Emrah ŞİMŞEK ${ }^{*}$, Alparslan YILDIRIM², Abdullah İNCİ², Önder DÜZLÜ², Erdal YILMAZ1, \\ Zuhal ÖNDER ${ }^{2}$, Arif ÇİLOĞLU², Gökmen Zafer PEKMEZCİ ${ }^{3}$
}

\author{
${ }^{1}$ Erciyes University, Faculty of Veterinary Medicine, Department of Aquatic Animal Diseases, 38039, Kayseri, Turkey \\ ${ }^{2}$ Erciyes University, Faculty of Veterinary Medicine, Department of Parasitology, 38039, Kayseri, Turkey \\ ${ }^{3}$ Ondokuz Mayis University, Faculty of Veterinary Medicine, Department of Aquatic Animal Diseases, 55200, Samsun, Turkey
}

\begin{abstract}
Posthodiplostomum Dubois, 1936 species have worldwide distribution. Metacercariae of P. cuticola that is common in Europe causes "black spot" disease in freshwater fishes. A limited number of data on mitochondrial and ribosomal sequences of $P$. cuticola are available in the GenBank. In addition, there is no sequencing data on trematodes belonging to genus of Posthodiplostomum in Turkey. The aim of this study was to investigate the presence of Posthodiplostomum metacercariae in freshwater chubs (Squalius cephalus) and to reveal the molecular characterization of mt-COI and ITS-2 gene regions of the identified isolates. Posthodiplostomum metacercariae were detected in the gills of two $(1.6 \%)$ out of 123 fish. The ITS-2 gene sequences of the isolates (POSTC1-C2) (MN701652-3) found in this study showed 99.8-100\% identity with P. cuticola sequences isolated from skin, muscle and fins of different fish species in Czech Republic and Hungary. In addition, the mtCOI gene sequences of the POSTC1-C2 isolates (MN700658-9) showed 99.1-98.9\% identity with P. cuticola isolate (cercariae) (KX931424) from Planorbis planorbis in Lithuanian. This study provides first molecular and phylogenetic characterization of $P$. cuticola isolates found in chubs (Squalius cephalus) in Turkey.
\end{abstract}

Keywords: ITS-2 and mt-COI gene regions, Molecular characterization, Posthodiplostomum cuticola, Squalius cephalus, Turkey.

Türkiye'de Tatlı Su Kefali'nin (Squalius cephalus) Solungaçlarını Enfekte Eden Posthodiplostomum cuticola (von Nordmann, 1832) Dubois, 1936 (Trematoda: Diplostomidae) Metaserkerlerinin İlk Moleküler Karakterizasyonu

ÖZ

Posthodiplostomum Dubois, 1936 türleri dünya genelinde oldukça yaygınlık göstermektedirler. Avrupa'da yaygın olan $P$. cuticola türünün metaserkeri tatlı su balıklarında siyah nokta "black spot" hastalığına sebep olmaktadır. GenBank veri tabanında $P$. cuticola türüne ilişkin mitokondriyal ve ribozomal sekans kaydı sınırlıdır. Diğer yandan, Türkiye'de Posthodiplostomum cinsinde yer alan trematodların sekans karakterizasyonuna dair herhangi bir veri bulunmamaktadır. Bu çalışmada, tatlı su kefallerinde (Squalius cephalus) Posthodiplostomum metaserkerlerinin araştırılması ve tespit edilen izolatların mt-COI ve ITS-2 gen bölgelerinin moleküler karakterizasyonlarının yapılması amaçlanmıştır. İncelenen 123 balıktan ikisinin $(\% 1,6)$ solungaçlarında Posthodiplostomum metaserkerleri saptanmıștır. Çalıșmada tespit ettiğimiz izolatların (POSTC1-C2) (MN701652-3) ITS-2 gen bölgesine ait nükleotid dizilimleri, Çek Cumhuriyeti ve Macaristan'da farklı balık türlerinin deri, kas ve yüzgeçlerinden izole edilen P. cuticola izolatları ile \%99,8-100 arasında identiklik göstermiştir. Yine POSTC1-C2 izolatlarının (MN700658-9) mtCOI gen bölgesine ait nükleotid dizilimleri, Litvanya'da Planorbis planorbis'te bulunan P. cuticola izolatı (serker) (KX931424) ile \%99,1-98,9 oranında identik bulunmuştur. Bu çalışma ile Türkiye'de ilk kez tatlı su kefalinde (Squalius cephalus) bulunan $P$. cuticola izolatlarının moleküler ve filogenetik karakterizasyonları ortaya konulmuştur.

Anahtar Kelimeler: ITS-2 ve mt-COI gen bölgeleri, Moleküler karakterizasyon, Posthodiplostomum cuticola, Squalius cephalus, Türkiye.

To cite this article: Simsek E. Yuldum A. Inci A. Düzlü Ö. Yulmaz E. Önder Z. Ciloğlu A. Pekmezci G.Z. First Molecular Characterization of Posthodiplostomum cuticola (von Nordmann, 1832) Dubois, 1936 (Trematoda: Diplostomidae) Metacercariae Infecting The Gills of Chubs (Squalius cephalus) in Turkey. Kocatepe Vet J. (2020) 13(1):45-51. 


\section{GİRİŞ}

Posthodiplostomum Dubois, 1936 cinsinde yer alan türler dünya genelinde oldukça yaygınlık göstermektedirler (Niewiadomska 2002). Yaşam döngülerinde salyangozlar (birinci ara konak), balıklar (ikinci ara konak) ve balıkla beslenen kuşlar (son konak) olmak üzere üç konak bulunmaktadır (Dönges 1964). Posthodiplostomum sp. ile enfekte balıklarda gelişme geriliği ve ağırlık kaybı gözlenmekle birlikte, oluşan lezyonlara bağlı olarak, balıkların pazar kalitesi düşmektedir (Lane ve Morris 2000). Bunun yanı sıra metaserkerlerle enfekte balıklar son konak olan kuşlara daha kolay yem olabilmektedir (Ondračková ve ark. 2006).

Avrupa'da çeşitli balık türlerinde P. cuticola (von Nordmann 1832) Dubois, 1936 ve P. brevicaudatum (von Nordmann 1832) Dubois, 1936 olmak üzere iki tür tanımlanmış ve yalnızca bu iki türün varlığı kabul ediliyorken, son yıllarda yapılan moleküler tabanlı çalışmalarda daha çok Kuzey Amerika'da yaygınlık gösteren P. minimum (McCallum 1921) Dubois, 1936 ve $P$. centrarchi Hoffman, 1958 türlerinin de Avrupa'da farklı konak türlerinde varlığı ortaya çıkarılmıştır (Kvach ve ark. 2017, Stoyanov ve ark. 2017). Moleküler veriler Kuzey Amerika, Avrupa ve Asya gibi farklı coğrafyalarda doğal enfekte konaklardan izole edilen trematod türlerinin doğru bir şekilde tür identifikasyonlarının yapılmasında, gelişim dönemleri arasındaki ilişkilerin kurulmasında ve doku/konak spesifitelerinin belirlenmesinde sıklıkla kullanılmıştır (Moszczynska ve ark. 2009, Locke ve ark. 2010, Nguyen ve ark. 2012, Stoyanov ve ark. 2017, Kvach ve ark. 2017, López-Hernández ve ark. 2018, Hoogendoorn ve ark. 2019). Bunun yan1 sira moleküler tabanlı çalışmalar kriptik türlerin tanımlanmasını, trematod çeşitliliğinin belirlenmesini ve yaşam döngülerinin daha iyi anlaşılmasını da sağlamıştır (Poulin 2011).

Avrupa'da yaygınlık gösteren $P$. cuticola türünün metaserkerleri Türkiye'de Eber ve Sapanca Gölü'nden yakalanan sazan (Cyprinus carpio) balıklarında morfolojik olarak tespit edilmiştir (Öztürk 2005, Uzunay ve Soylu 2006). Bunun dişında Aşağ1 Kizılırmak Deltasından yakalanan Neogobius fluviatilis ve Proterorbinus marmoratus balık türlerinde morfolojik olarak Posthodiplostomum sp. rapor edilmiştir (Güven ve Öztürk 2018). Ancak, bugüne kadar Türkiye'de Posthodiplostomum cinsinde yer alan trematodlar üzerine moleküler tabanlı araştırmaların yapılmadığı dikkati çekmiştir. Günümüzde Posthodiplostomum cinsinde yer alan trematodların tür teşhislerinin doğru bir şekilde yapılabilmesi için mt-COI ve ITS gen bölgelerinin PCR ve sekans analizleri siklıkla kullanılmaktadir (Stoyanov ve ark. 2017, Boone ve ark. 2018, LópezHernández ve ark. 2018, Hoogendoorn ve ark. 2019). $\mathrm{Bu}$ çalışmada, tatlı su kefalinde (Squalius cephalus) bulunan Posthodiplostomum izolatlarının mt-COI ve
ITS-2 gen bölgelerinin sekans analizleri yapılarak Türkiye'deki ilgili parazit nesilleri için ilk moleküler karakterizasyon verileri ortaya çıkarılmıştır.

\section{MATERYAL ve METOT}

\section{Örneklerin Toplanması ve Parazitolojik İncelemeler}

Kasım 2016 ve Kasım 2018 tarihleri arasında İç Anadolu Bölgesi, Kayseri İli'ndeki yerel balıkçılardan satın alınarak uygun taşıma koşullarında Erciyes Üniversitesi Veteriner Fakültesi Su Ürünleri ve Hastalıkları Laboratuvarına getirilen toplam 123 adet tatlı su kefali (Squalius cephalus) parazitolojik açıdan incelenmiştir. Balıkların vücut yüzeyleri, yüzgeçleri ve solungaçları stereo mikroskop (Olympus SZX10 Tokyo, Japan) altında dikkatlice incelendikten sonra nekropsileri gerçekleștirilmiştir. Tüm balıkların karın boşlukları, iç organları ve kas dokuları ayrı ayrı metaserker varlığ1 açısından muayene edilmiştir. Siyah görünümlü kistlere yalnızca solungaçlarda rastlanmıştır. Solungaçlardan toplanan kistler fizyolojik tuzlu su içerisinde doku artıklarından temizlendikten sonra moleküler analizlerde kullanılmak üzere \% $\% 0^{\prime}$ lik alkol içerisinde $+4^{\circ} \mathrm{C}$ 'de saklanmıştır.

\section{Metaserkerlerden Genomik DNA İzolasyonu, ITS-2 ve mt-COI Gen Bölgelerinin Amplifikasyonu}

Alkolü uzaklaştırilan metaserkerlerin genomik DNA (gDNA) ekstraksiyonlar1 ticari kit (GeneJET Genomic DNA Purification Kit, Thermo Scientific, Waltham, MA, USA) kullanılarak gerçekleştirilmiş ve elde edilen gDNA'lar $-20^{\circ} \mathrm{C}$ 'de saklanmıştır.

Örneklerden izole edilmiş olan gDNA ekstraktları, metaserkerlerin ITS-2 ve mt-COI gen bölgelerini amplifiye eden OPHET_Fwd/OPHET_Rev (Skov ve ark. 2009) ve Dice1F/Dice11R (Van Steenkiste ve ark. 2015) primerleri ile PCR analizlerine tabii tutulmuştur. PCR reaksiyon karışımı $25 \mu \mathrm{l}$ final konsantrasyonda; 12,5 $\mu$ l ticari master mix (Maxima Hot Start PCR Master Mix, Thermo Scientific, Waltham, MA, USA), 0,5 $\mu \mathrm{M}$ her bir primer ve 10-50 ng gDNA içerecek şekilde hazırlanmıştır. PCR cihazinda (Applied Biosystems, Thermo Scientific, Waltham, MA, USA) protokoller; mt-COI gen bölgesi için Van Steenkiste ve ark. (2015)'a göre ayarlanmış, ITS-2 gen bölgesi için ise $95^{\circ} \mathrm{C}$ de $4 \mathrm{dk} ; 30$ siklus, denatürasyon: $95^{\circ} \mathrm{C}$ 'de $30 \mathrm{sn}$, bağlanma: $52^{\circ} \mathrm{C}$ 'de 30sn, uzama: $72^{\circ} \mathrm{C}^{\prime} \mathrm{de} 1 \mathrm{dk}$ ve final uzama: $72^{\circ} \mathrm{C}^{\prime} \mathrm{de} 10$ $\mathrm{dk}$ olacak şekilde belirlenmiştir. Amplifikasyon sonunda elde edilen PCR ürünleri $\left(\begin{array}{ll}10 & \mu l\end{array}\right)$ SafeViewTM (Applied Biological Materials Richmond, BC, Canada) ile boyanarak \%1,5 'luk agaroz jelde elektroforeze tabi tutulmuş, jel görüntülemeleri ve analizleri Quantum CX5 jel dökümantasyon sisteminde (Vilber Lourmat, France) gerçekleştirilmiştir. 
DNA Dizi (Sekans) ve Filogenetik Analizleri

Ticari kit (High Pure PCR Product Purification Kit, Roche, Germany) kullanılarak jelden pürifiye edilen her bir gen bölgesine ait PCR ürünleri, ilgili forward ve reverse primerleri ile çift yönlü olarak sekanslanmışıı (Macrogen, Amsterdam). İzolatların elde edilen çift yönlü DNA dizilerinin kromotogram kalite skorları dikkate alınarak Geneious 11.0.2 yazılımında forward ve reverse dizilimleri birleştirilmiş ve metaserkerlere ait final dizilimler elde edilmiștir (Kearse ve ark. 2012). Final dizilimlerinin Geneious 11.0.2 yazlımı üzerinden BLASTn analizleri gerçekleştirilerek metaserkerlerin tür identifikasyonları yapilmıştır (Kearse ve ark. 2012). Daha sonra GenBank'a, farklı coğrafik bölgelerden kaydedilmiş Posthodiplostomum türleri ve yakın cinsler içerisinde yer alan bazı izolatlar seçilerek, her iki gen bölgesi için veri setleri oluşturulmuş ve Geneious 11.0.2 yazılımında çoklu hizalamaları yapılmıştır (Kearse ve ark. 2012). MEGA 7.0 genetik yazılımı üzerinden Kimura two-parameter modeli kullanılarak tür içi ve arası nükleotid farklılıkları (\%) belirlenmiştir (Kimura 1980, Kumar ve ark. 2016).

Filogenetik ilişkilerin belirlenmesinde, Geneious 11.0.2 yazılım programinda JC+G (ITS-2) ve $\mathrm{GTR}+\mathrm{G}$ (mt-COI) modellerini temel alan Bayesian (BA) [MrBayes version 3.2.6 (Huelsenbeck ve Ronquist 2001)] analizi uygulanmıştır (Kearse ve ark. 2012). Sekans evrimi için en uygun DNA modelleri Akaine Information Criterion (AIC) kriterlerine göre MEGA 7.0 genetik yazılımında belirlenmiştir (Kumar ve ark. 2016).

Tylodelphys mashonensis [KC685363 (ITS); KR863382 (mt-COI)] her iki filogenetik ağaçta diş dal olarak kullanılmıştır. Karakterizasyonu sağlanan $P$. cuticola izolatlarının (POSTC1-C2) ITS-2 ve mt-COI gen bölgelerine ait DNA dizileri (ITS-2; MN701652-3 ve mt-COI; MN700658-9) erişim numaralarıly GenBank veri tabanına kaydedilmiştir.

\section{BULGULAR}

İncelenen 123 balıktan ikisinin $(\% 1,6)$ solungaçlarında birer adet olmak üzere Posthodiplostomum sp. metaserkeri bulunmuştur. Kistler stereo mikroskop altında dikkatlice patlatılarak metaserkerlerin serbest kalması sağlanmıştır. Serbest kalan metaserkerlerin vücut yapilarının deforme olduğu görülmüş ve morfolojik yapıları görüntülenememiştir. İzolatların ITS-2 ve mt-COI gen bölgelerine ait sekanslar1 başarılyla elde edilmiştir. Metaserkerlerin her iki gen bölgesine ait sekansları, BLASTn analizine göre $P$. cuticola olarak identifiye edilmiş ve POSTC1-C2 izolat isimleriyle GenBank veri tabanına kaydedilmiştir.

POSTC1-C2 izolatlarının ITS-2 gen bölgesinin sekans analizleri sonucunda 444bp uzunluğunda DNA dizisi elde edilmiştir. ITS-2 gen bölgesine ait veri seti oluşturulurken çoklu hizalamaları yapılan izolatların dizi uzunlukları 444bp olarak düzenlenmiştir. Çalışmada karakterize edilen izolatların ITS-2 nükleotid dizilimleri arasındaki tür içi genetik farklılık saptanmamıstır. ITS-2 gen bölgesine göre çalışmada bulunan izolatlar, Çek Cumhuriyeti'nde Leuciscus cephalus ve Blicca bjoerkna'dan, Macaristan'da Abramis brama, Rutilus rutilus, B. bjoerkna ve Scardinius erythrophthalmus'tan rapor edilen P. cuticola (MF17101416; MN080286,89-92) izolatlar1 ile \%100 identiklik gösterirken, yine Macaristan'da $A$. brama'dan bildirilen P. cuticola (MN080287) izolat1 ile $\% 0,2$ nükleotid farklllığ göstermiştir. ITS-2 veri setine dahil edilen ve farklı coğrafik bölgelerden GenBank'a kayıtları gerçekleştirilmiş $P$. nanum, $P$. cf. minumum, $P$. centrarchi ve $P$. brevicaudatum türleriyle POSTC1-C2 izolatlar1 arasındaki nükleotid farklılıkları sırasıyla \%4,2-6,7; $\% 7,1-7,7 ; \% 4,8-6,4 ; \% 3,7$ aralığında belirlenmiștir. Bunun yanı sira yine GenBank'a Posthodiplostomum sp. olarak kaydedilmiş izolatlar ile bu çalışmadaki izolatlar arasında $\% 4,8-8$ nükleotid farklilığ1 olduğu görülmüştür.

POSTC1-C2 izolatlarının mt-COI gen bölgesinin sekans analizleri sonucunda 577bp uzunluğunda DNA dizisi elde edilmiştir. Mt-COI gen bölgesine ait veri seti oluşturulurken çoklu hizalamaları yapilan izolatların dizi uzunlukları 352bp olarak düzenlenmiştir. Çalışmada karakterize edilen izolatların mt-COI nükleotid dizilimleri arasındaki tür içi genetik farklılıkları \%0,3 olarak belirlenmiştir. POSTC1-C2 izolatlarının mt-COI gen bölgesine ait nükleotid dizilimleri, BLASTn analizlerine göre, Litvanya'da Planorbis planorbis'te bulunan KX931424 erişim numaralı izolatla (serker) \%098,9-99,1 oranında identik bulunmuștur. Mt-COI veri setine dahil edilen ve farklı coğrafik bölgelerden GenBank'a kayıtları gerçekleştirilmiş $P$. nanum, $P$. centrarchi ve $P$. brevicaudatum türleriyle POSTC1-C2 izolatlar1 arasındaki nükleotid farklılıkları sırasıyla $\% 19 ; \% 22$ 22,4; \%25,5-26,3 aralı̆̆ında belirlenmiştir. Bunun yanı sira yine GenBank'a Posthodiplostomum sp. düzeyinde kayıtlar1 gerçekleştirilmiş izolatlar ile POSTC1-C2 izolatları arasında \%16,7-25 nükleotid farklillğı olduğu görülmüştür. Mt-COI gen bölgesinin DNA dizi analizlerine göre Posthodiplostomum türleri arasındaki nükleotid farkl1lığın ITS-2'ye göre oldukça yüksek olduğu belirlenmiştir.

Her iki gen bölgesine ait filogenetik ağaçta iki ana cluster (dal) olușmuștur. Posthodiplostomum cuticola izolatları kendi aralarında gruplanarak diğer Posthodiplostomum türlerinden farklı bir clusterda (dalda) yer almıştır (Şekil. 1 ve 2). 


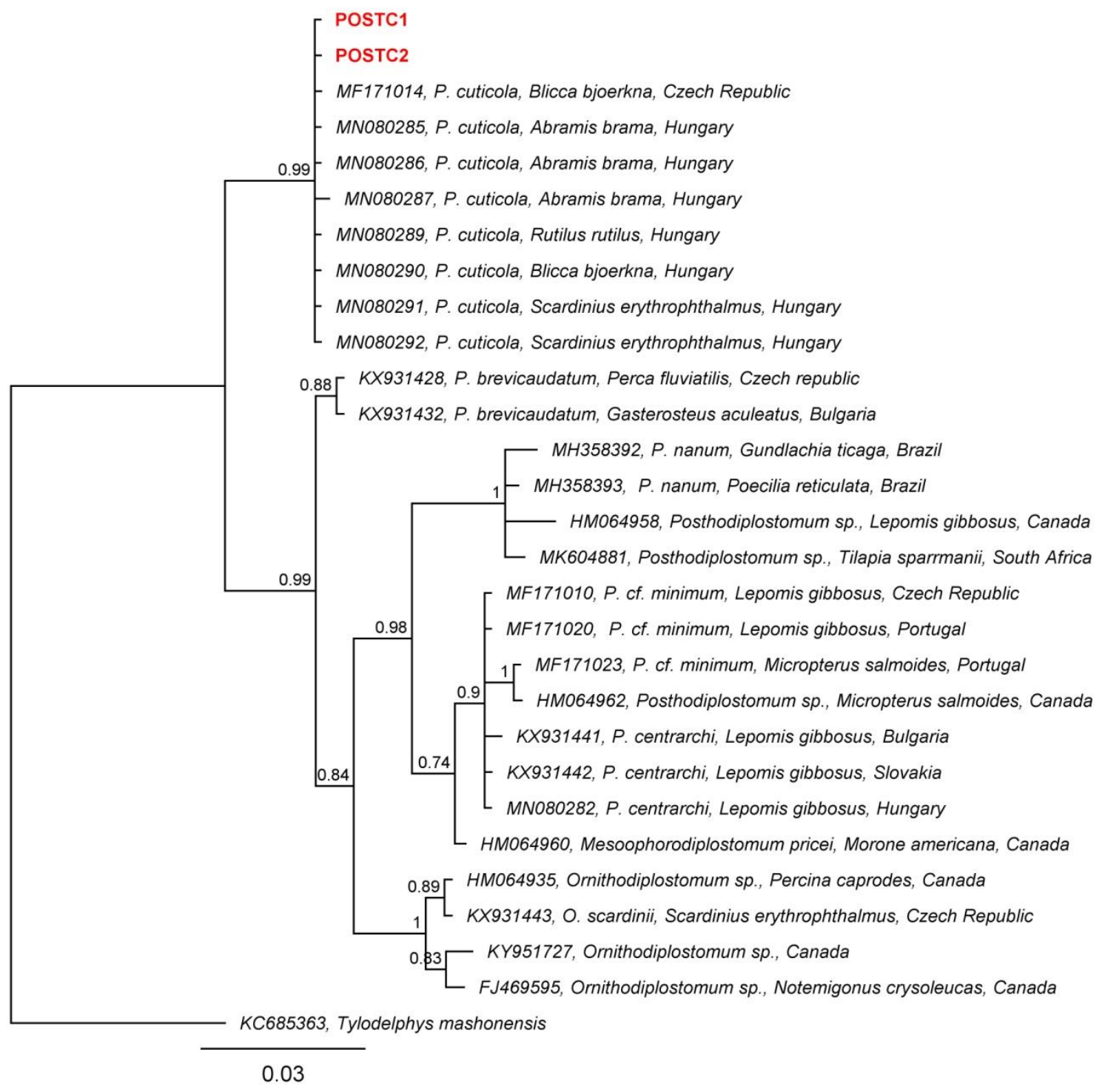

Şekil 1. Posthodiplostomum türlerinin ITS-2 gen bölgesine göre filogenetik ilișkileri. Tylodelphys mashonensis (KC685363) dış dal olarak kullanılmıştır. Veri setine dahil edilen izolatlar GenBank erişim numaraları, tür ismi, konak ve ülkeleri ile verilmiştir. Çalışmada bulunan izolatlar (POSTC1C2) kırmızı karakterde gösterilmiştir. Ölçek çizgisi \%0,03 farklılı̆̆1 göstermektedir.

Figure 1. Phylogenetic relationships among Posthodiplostomum species based on ITS-2 gene. Tylodelphys mashonensis (KC685363) was used as an out group. Isolates that is included in data sets were given with GenBank accession numbers, species names, hosts, and countries. The isolates (POSTC1-2) found in this study were shown with red character. Scale bar represents $0.03 \%$ substitutions per nucleotide position. 


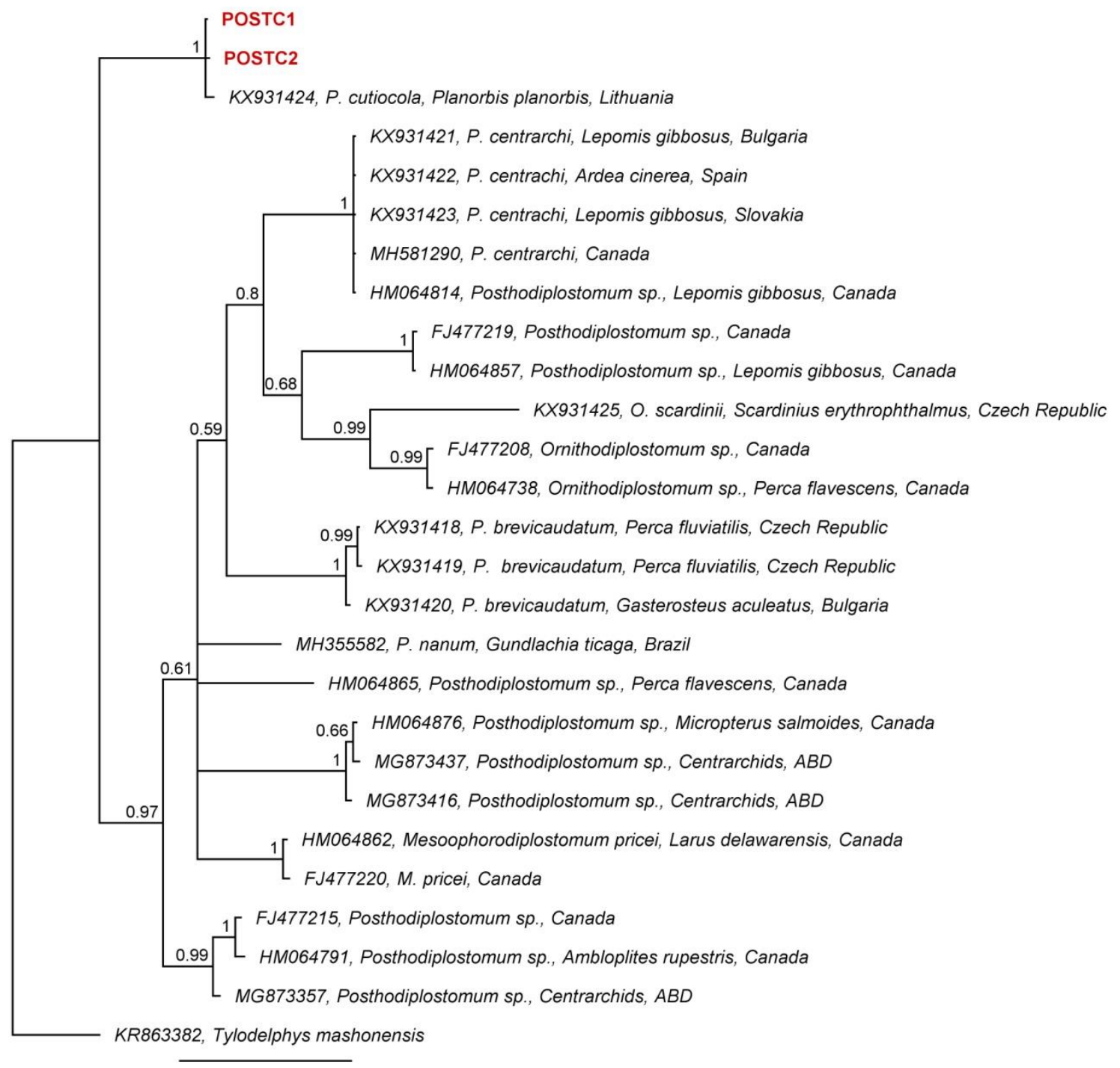

0.2

Şekil 2. Posthodiplostomum türlerinin mt-COI gen bölgesine göre filogenetik ilişkileri. Tylodelphys mashonensis (KR863382) diş dal olarak kullanılmışır. Veri setine dahil edilen izolatlar GenBank erişim numaraları, tür ismi, konak ve ülkeleri ile verilmiştir. Çalışmada bulunan izolatlar (POSTC1C2) kırmızı karakterde gösterilmiştir. Ölçek çizgisi \%0,2 farkllığı göstermektedir.

Figure 2. Phylogenetic relationships among Posthodiplostomum species based on mt-COI gene. Tylodelphys mashonensis (KR863382) was used as an out group. Isolates that is included in data sets were given with GenBank accession numbers, species names, hosts, and countries. The isolates (POSTC1-2) found in this study were shown with red character. Scale bar represents $0.2 \%$ substitutions per nucleotide position.

\section{TARTIŞMA}

Avrupa'da yaygınlık gösteren $P$. cuticola türünün metaserkerleri ikinci ara konak balıklarda deri, kas ve yüzgeç gibi farklı dokulara yerleşerek melanosit birikimine bağlı olarak siyah nokta ("black spot") hastalığına sebep olmaktadırlar (Dönges 1964). Bugüne kadar Türkiye'de, bu parazit türü ile ilgili yalnızca Aşağı Kızılırmak Deltası ile Eber ve Sapanca Göllerinden yakalanan birkaç farklı balık türünde (deri ve yüzgeçler) morfolojik düzeyde veriler bulunmaktadır. (Öztürk 2005, Uzunay ve Soylu 2006, Güven ve Öztürk 2018). Posthodiplostomum cuticola türüne ilişkin GenBank veri tabanında sınırlı sayıda sekans kaydı bulunmakla birlikte, Türkiye'den
Posthodiplostomum cinsinde yer alan trematodlara ait moleküler tabanlı herhangi bir veri bulunmamaktadır. $\mathrm{Bu}$ çalışma ile tatlı su kefalinde (Squalius cephalus) tespit edilen $P$. cuticola izolatlarını (POSTC1-C2) Türkiye'de ilk kez mt-COI ve ITS-2 gen bölgelerinin sekans analizleri yapilarak moleküler karakterizasyonları sağlanmış ve GenBank kayıtları gerçekleştirilmiştir.

$\mathrm{Bu}$ çalışmada, balıkların solungaçlarında bulunan izolatlar, ITS-2 gen bölgesinin analizlerine göre Çek Cumhuriyeti'nde ve Macaristan'da farklı balı türlerinin deri, kas ve yüzgeçlerinden izole edilen $P$. cuticola (MF171014-16; MN080286,87,89-92) izolatlar1 ile \%99,8-100 arasında identiklik göstermiştir. Veri 
setine dahil edilen Posthodiplostomum izolatlarının tür içi genetik farkl1lıklar1 \%0,0-0,5 iken, türler arası farklılık \%1,2-7,7 olarak belirlenmiştir. GenBank'a Posthodiplostomum sp. olarak kayıtları gerçekleștirilmiş izolatlar ile POSTC1-C2 izolatlar1 arasinda \%4,8-8 nükleotid farklılığ1 olduğu görülmüştür. Çalışmada karakterize edilen izolatların mt-COI nükleotid dizilimleri arasındaki tür içi genetik farklılıkları \%0,3 olarak belirlenmiştir. POSTC1-C2 izolatlarının mtCOI gen bölgesine ait nükleotid dizilimleri Litvanya'da $P$. planorbis'te bulunan $P$. cuticola izolat1 (serker) ile (KX931424) \%0,9-1,1 nükleotid farklilığ1 göstermiştir. Stoyanov ve ark. (2017)'nın da belirttiği gibi bu çalşsmada da mt-COI gen bölgesine göre Posthodiplostomum türlerinde tür içi genetik farklllik $(\% 0,0-1,7)$ türler aras1 farkl111ktan (\%16,5-26,3) oldukça düşük bulunmuştur. Bu durum mt-COI gen bölgesinin Posthodiplostomum türlerinin ayrımında kullanışlı bir belirteç olduğunu göstermektedir. Yine aynı çalışmanın (Stoyanov ve ark. 2017) sonuçlarına benzer şekilde mt-COI gen bölgesinin DNA dizi analizlerine göre Posthodiplostomum türleri arasındaki nükleotid farklılı̆̆ın ITS-2'ye göre oldukça yüksek olduğu görülmüştür. Çalışmamızda her iki gen bölgesine ait filogenetik ağaçta parazit türleri iki ana dalda yer almıştır. Posthodiplostomum cuticola izolatları, çeşitli araştırmalardaki (Kvach ve ark. 2017, LópezHernández ve ark. 2018, Hoogendoorn ve ark. 2019) filogenetik yapılanmaya benzer şekilde kendi aralarında monofiletik olarak gruplanarak, diğer türlerden farklı bir dalda yer almış ve bu türün Posthodiplostomum'un evrimsel sürecinde ve taksonomisinde oldukça önemli bir yere sahip olduğu dikkati çekmiştir. Bazı çalışmalarda da belirtildiği gibi (López-Hernández ve ark. 2018, Hoogendoorn ve ark. 2019), GenBank veri tabanında Posthodiplostomum sp. olarak kayttlı bir izolat (HM064962), P. of. minumum, $P$. centrarchi izolatlar1 ile $\% 0,0-0,8$, Mesoophorodiplostomum pricei izolat1 ile ise \%0,8 nükleotid farklllığ göstermiş olup, ITS-2 filogenetik ağacında söz konusu izolatlar ile aynı grupta yer aldığ1 görülmüştür (posterior olasıllk 0,74). Dolayısıyla, ITS filogenesi dikkate alındığında, Posthodiplostomum ve Mesoophorodiplostomum'un sinonim olarak adlandırılabileceği belirtilmiştir (López-Hernández ve ark. 2018). Yine GenBank veri tabanında Posthodiplostomum sp. olarak kayitli baz1 izolatlar (FJ477219; HM064857) Ornithodiplostomum sp. ve O. scardinii izolatlar1 (FJ477208; HM06473; KX931425) ile \%16,7-22,4 nükleotid farklilığ1 göstererek, mt-COI filogenetik ağacında söz konusu izolatlar ile aynı grupta yer almıştır (posterior olasılık 0,68). Filogenetik analizler 1şı̆̆ında Posthodiplostomum cinsinde yer alan türler ile diğer yakın cinslerde bulunan trematodlar arasındaki filogenetik ilişkiler daha detaylı bir şekilde araştırılarak tür içi ve türler arası nükleotid farklılıkların kabul edilebilir aralığının belirlenmesi gerektiği kanısına varilmıştır. Nitekim LópezHernández ve ark. (2018) daha önce GenBank veri tabanına Posthodiplostomum olarak kayıtları yapılmış olan bazı izolatların hatalı olabileceğini, yine bu cins içerisinde ya da Mesoophorodiplostomum cinsi içerisinde yer alan bazı izolatların tekrardan tanımlanması gerektiğini vurgulamaktadırlar.

Sonuç olarak, bu çalışma ile P. cuticola izolatlarının Türkiye'de ilk kez moleküler ve filogenetik karakterizasyonları ortaya konulmuştur. Türkiye'de Posthodiplostomum türlerinin tür ve genetik çeşitliliğinin, birinci ara konak ve son konaklarinin ve bu konaklardaki dağılımlarının belirlenmesi için daha geniş bir coğrafyada moleküler ve morfolojik yöntemlerin birlikte kullanıldığı çalışmaların yürütülmesi gerekmektedir.

\section{TEŞEKKÜR}

> $\mathrm{Bu}$ çalışma, TCD-2016-6795 proje koduyla Erciyes Üniversitesi Bilimsel Araştırma Projeleri Birimi tarafindan desteklenmiştir.

Çıkar Çatışması: Yazarlar, çıkar çatışması olmadığını beyan eder.

\section{KAYNAKLAR}

Boone EC, Laursen JR, Colombo RE, Meiners SJ, Romani MF, Keeney DB. Infection patterns and molecular data reveal host and tissue specificity of Posthodiplostomum species in centrarchid hosts. Parasitology. 2018; 145(11):1458-1468.

Dönges J. Der Lebenszyklus von Posthodiplostomum cuticola (v. Nordmann, 1832) Dubois, 1936 (Trematoda, Diplostomatidae). Z Parasitenk. 1964; 24(2):169-248.

Güven A, Öztürk T. Metazoan parasite faunas of three Gobiid species (Actinopterygii: Gobiidae) inhabiting the lower Krzilırmak Delta in Samsun: A comparative study. Türkiye Parazitol Derg. 2018; 42: 33-38.

Hoogendoorn C, Smit NJ, Kudlai O. Molecular and morphological characterisation of four diplostomid metacercariae infecting Tilapia sparrmanii (Perciformes: Cichlidae) in the North West Province, South Africa. Parasitol Res. 2019; 118: 1403-1416.

Huelsenbeck JP, Ronquist F. MRBAYES: Bayesian inference of phylogenetic trees. Bioinformatics. 2001; 17:754-755.

Kearse M, Moir R, Wilson A, Stones-Havas S, Cheung M, Sturrock S, Buxton S, Cooper A, Markowitz S, Duran C, Thierer T, Ashton B, Meintjes P, Drummond A. Geneious Basic: An integrated and extendable desktop software platform for the organization and analysis of sequence data. Bioinformatics. 2012; 28:1647-1649.

Kimura M. A simple method for estimating evolutionary rate of base substitutions through comparative studies of nucleotide sequences. J Mol Evol. 1980; 16:111-120.

Kumar S, Stecher G, Tamura K. MEGA7: Molecular evolutionary genetics analysis version 7.0 for bigger datasets. Mol Biol Evol. 2016; 33(7):1870-1874.

Kvach Y, Jurajda P, Bryjová A, Trichkova T, Ribeiro F, Přikrylová I, Ondračková M. European distribution for metacercariae of the North American digenean Posthodiplostomum cf. minimum centrarchi (Strigeiformes: Diplostomidae). Parasitol Int. 2017; 66:635-642. 
Lane RL, Morris, JE. Biology, prevention and effects of common grubs (digenetic trematodes) in freshwater fish. Tech. Bull. 2000; 115: 1-6.

Locke SA, McLaughlin JD, Marcogliese DJ. DNA barcodes show cryptic diversity and a potential physiological basis for host specificity among Diplostomoidea (Platyhelminthes: Digenea) parasitizing freshwater fishes in the St. Lawrence River, Canada. Mol Ecol. 2010; 19: 2813-2827.

López-Hernández D, Locke SA, de Melo AL, Rabelo ÉML, Pinto HA. Molecular, morphological and experimental assessment of the life cycle of Posthodiplostomum nanum Dubois, 1937 (Trematoda: Diplostomidae) from Brazil, with phylogenetic evidence of the paraphyly of the genus Posthodiplostomum Dubois, 1936. Infect Genet Evol 2018; 63:95-103.

Moszczynska A, Locke S, McLaughlin J, Marcogliese D, Crease T. Development of primers for the mitochondrial cytochrome c oxidase I gene in digenetic trematodes (Platyhelminthes) illustrates the challenge of barcoding parasitic helminths. Mol Ecol Resour. 2009; 9:75-82.

Nguyen TC, Li YC, Makouloutou P, Jimenez LA, Sato H. Posthodiplostomum sp. metacercariae in the trunk muscle of northern snakeheads (Channa argus) from the Fushinogawa River, Yamaguchi, Japan. J Vet Med Sci. 2012; 74: 1367-1372.

Niewiadomska K. Superfamily Diplostomoidea Poirier, 1886, In: Keys to the Trematoda, Ed; Gibson DI, Jones A, Bray RA, $1^{\text {th }}$ Ed., CAB International and The Natural History Museum, UK. 2002; pp. 159-242.

Ondračková M, Dávidová M, Gelnar M, Jurajda $P$. Susceptibility of Prussian carp infected by metacercariae of Posthodiplostomum cuticola (v. Nordmann, 1832) to fish predation. Ecol Res. 2006; 21: 526-529.

Öztürk MO. Eber Gölü (Afyon)'ndeki Sazan (Cyprinus carpio L.)'ların metazoon parazitleri üzerine bir araştırma. Türkiye Parazitol Derg. 2005; 29(3):204-210.

Poulin R. Uneven distribution of cryptic diversity among higher taxa of parasitic worms. Biol Lett 2011; 7: 241-244.

Skov J, Kania PW, Dalsgaard A, Jørgensen TR, Buchmann K. Life cycle stages of heterophyid trematodes in Vietnamese freshwater fishes traced by molecular and morphometric methods. Vet Parasitol. 2009; 160:66-75.

Stoyanov B, Georgieva S, Pankov P, Kudlai O, Kostadinova A, Georgiev BB. Morphology and molecules reveal the alien Posthodiplostomum centrarchi Hoffman, 1958 as the third species of Posthodiplostomum Dubois, 1936 (Digenea: Diplostomidae) in Europe. Syst Parasitol. 2017; 94:1-20.

Uzunay E, Soylu E. Sapanca Gölü'nde yaşayan Sazan (Cyprinus carpio Linnaeus, 1758) ve Karabalı (Vimba vimba Linnaeus, 1758)'in metazoan parazitleri. Türkiye Parazitol Derg. 2006; 30(2):141-150.

Van Steenkiste N, Locke SA, Castelin M, Marcogliese DJ, Abbott CL. New primers for DNA barcoding of digeneans and cestodes (Platyhelminthes). Mol Ecol Resour. 2015; 15:945-952. 